\title{
An Analysis of Foreign Exchange Reserves in India since 2001- 2016
}

\author{
Saba Abid , Neelam Jhawar \\ 4490, Shahtara Street, Ajmeri Gate, Delhi 110006
}

\begin{abstract}
The study is aimed at analysing the trend in Foreign Exchange Reserves and its components in India. The period of the study is defined from 2011 to 2016 and is based on secondary data.
\end{abstract}

Keywords: Sdrs, IMF, FOREX, RTP.

\section{Introduction}

In simplest terms foreign exchange reserves are the foreign currencies which are held by the central bank to support liabilities on the issued currency and also a way to influence the monetary policies of the country. It includes government securities, bonds, bank notes, bank deposits and treasury bills.

Regardless of the size of the economy almost all countries in the economy hold significant foreign exchange reserves and most of them being held in U.S dollars which is the most traded currency. Other currencies in reserves are British pound sterling, euro, Chinese Yuan, and Japanese Yen. Theorists believe that holding reserves in currencies which is not immediately connected to its own is best policy. As of April 2016 China holds the largest foreign exchange reserves $\$ 3520.4$ billion.

The holding of forex is used to back the one's domestic currency. Countries who wish to have fixed exchange rate uses forex reserves as a tool of monetary policy. Central institution has ability to exert some control over exchange rates by retaining the option to shove reserves from another currency in to the market.

\section{Components Of Foreign Exchange Rserves Special Drwaing Rights}

"The SDR is an international reserve asset, created by the IMF in 1969 to supplement its member countries' official reserves. As of March 2016, 204.1 billion SDRs (equivalent to about $\$ 285$ billion) had been created and allocated to members. SDRs can be exchanged for freely usable currencies. The value of the SDR is based on a basket of five major currencies - the U.S. dollar, euro, the Chinese renminbi (RMB), the Japanese yen, and pound sterling — as of October 1, 2016."-IMF

\section{The role of the SDR}

"The SDR was created by the IMF in 1969 as a supplementary international reserve asset, in the context of the Bretton Woods fixed exchange rate system. A country participating in this system needed official reserves - government or central bank holdings of gold and widely accepted foreign currencies - that could be used to purchase its domestic currency in foreign exchange markets, as required to maintain its exchange rate. But the international supply of two key reserve assets - gold and the U.S. dollar-proved inadequate for supporting the expansion of world trade and financial flows that was taking place. Therefore, the international community decided to create a new international reserve asset under the auspices of the IMF". -IMF

\section{Gold Reserves}

"Gold played a central role in the international monetary system until the collapse of the Bretton Woods system of fixed exchange rates in 1973. Since then, its role has diminished. But it remains an important asset in the reserve holdings of several countries, and the IMF is still one of the world's largest official holders of gold. In line with the new income model for the Fund agreed in April 2008, profits from limited gold sales were used to establish an endowment, and used to boost the IMF's concessional lending capacity to eligible low-income countries (LICs).

The IMF holds around 90.5 million ounces (2,814.1 metric tons) of gold at designated depositories. On the basis of historical cost, the IMF's total gold holdings are valued at SDR 3.2 billion (about $\$ 4.5$ billion), but at current market prices, their value is about SDR 80.1 billion (about $\$ 112.7$ billion).

The IMF acquired its gold holdings through four main channels:

- When the IMF was founded in 1944 it was decided that 25 percent of initial quota subscriptions and subsequent quota increases were to be paid in gold. This represents the largest source of the IMF's gold. 
- All payments of charges (interest on member countries' use of IMF credit) were normally made in gold.

- A member wishing to acquire the currency of another member could do so by selling gold to the IMF. The major use of this provision was sales of gold to the IMF by South Africa in 1970-71.

- Member countries could use gold to repay the IMF for credit previously extended.

The Second Amendment to the Articles of Agreement in April 1978 fundamentally changed the role of gold in the international monetary system by eliminating its use as the common denominator of the post-World War II exchange rate system and as the basis of the value of the Special Drawing Right (SDR). It also abolished the official price of gold and ended its obligatory use in transactions between the IMF and its member countries. It furthermore required the IMF, when dealing in gold, to avoid managing the price of gold, or establishing a fixed price."

\section{Reserve Tranche Position}

International Monetary fund is financed by member's quota. Each member of the IMF is assigned a quota part of which is payable in SDR's or specified useable currencies (Reserve Assets) and part in member's own currency. The difference between a member's quota and the IMF's holding of its currency is a country's Reserve Tranche Position (RTP). The reserve tranche position of the quota can be accessed by the member at any time, whereas the rest of the member's is typically inaccessible.

\section{Importance Of Foreign Exchange Reserves}

Foreign exchange reserves increases the confidence in the monetary policies as well as exchange rate policies of the government. The capacity of the central bank to intervene in foreign exchange market and to control any adverse movement is enhanced. Also the capacity to stabilize the forex rates to provide more favourable economic environment for the country is also enhanced.

During the crises forex reserves come to the rescue of any country and absorb the distress or shocks. Domestic currency gets backed by external assets and is good for equity market since the forex reserves are strong then people from different countries wants to invest in the country.

\section{Objective Of The Study}

- To understand the theoretical framework of forex reserves and their significance in the economic development.

- To statistically analyze the trends in the Forex Reserves of India.

\section{Sources of data:}

\section{Research Methodology}

Data for the study is collected from Secondary sources. The study is based on published sources of data collected from journals, magazines, websites likes i.e www.rbi.org.in,Central Statistical Organization (CSO), Handbook of Statistics on the Indian economy were used.

\section{Period of study:}

The data for this study was collected from the time period 2011 to 2015.

\section{Statistical Analysis Of Trends In Forex Reserves In India}

Foreign currency reserves are crucial to a nation's economic welfare. Without sufficient reserves, an economy can crush to a halt. The country may be incapable to pay for essential imports like crude oil, or service its external debt.

“The International Monetary Fund (IMF) defines reserve assets as external assets that a country's monetary authority can use to meet balance of payments financing needs, use to affect currency exchange rates in currency exchange markets, and other related purposes. Most nations hold the vast majority of their foreign currency reserves in U.S. dollars and a much smaller portion in euros." -IMF

Ranking of countries according to their forex reserves holding.

\begin{tabular}{|l|l|l|}
\hline Rank & Country & $\begin{array}{l}\text { Official Reserve Assets (in billions of } \\
\text { U.S. dollars) }\end{array}$ \\
\hline 1 & China & $\$ 3,520.4$ \\
\hline 2 & Japan & $\$ 1,321$ \\
\hline 3 & Euro Area & $\$ 819.9$ \\
\hline 4 & Switzerland & $\$ 661.2$ \\
\hline 5 & Saudi Arabia & $\$ 580.7$ \\
\hline 6 & Russian Federation & $\$ 407.3$ \\
\hline
\end{tabular}




\begin{tabular}{|l|l|l|}
\hline 7 & Hong Kong & $\$ 380.2$ \\
\hline 8 & Republic of Korea & $\$ 372.6$ \\
\hline 9 & India & $\$ 366.2$ \\
\hline 10 & Brazil & $\$ 362.2$ \\
\hline
\end{tabular}

(Source: http://data.imf.org)

Foreign Exchange Reserves in Indian Currency from 2001 to 2015 (in billion).

\begin{tabular}{|l|l|l|l|l|l|}
\hline Year (End of March) & Gold & RTP & SDR & $\begin{array}{l}\text { Foreign Currency } \\
\text { Assets }\end{array}$ & Total \\
\hline 2001 & 127 & 29 & 0.11 & 1845 & 2001 \\
\hline 2002 & 149 & 30 & 0.5 & 2491 & 2670 \\
\hline 2003 & 168 & 32 & 0.19 & 3415 & 3615 \\
\hline 2004 & 182 & 57 & 0.1 & 4662 & 4901 \\
\hline 2005 & 197 & 63 & 0.2 & 5931 & 6191 \\
\hline 2006 & 257 & 34 & 0.12 & 6473 & 6764 \\
\hline 2007 & 296 & 20 & 0.08 & 8366 & 8682 \\
\hline 2008 & 401 & 17 & 0.74 & 11960 & 12380 \\
\hline 2009 & 488 & 50 & 0.06 & 12301 & 12839 \\
\hline 2010 & 812 & 62 & 226 & 11497 & 12597 \\
\hline 2011 & 1026 & 132 & 204 & 12249 & 13610 \\
\hline 2012 & 1383 & 145 & 229 & 13305 & 15061 \\
\hline 2013 & 1397 & 125 & 235 & 14126 & 15884 \\
\hline 2014 & 1296 & 110 & 268 & 16609 & 18284 \\
\hline 2015 & 1192 & 81 & 249 & 19855 & 21376 \\
\hline SOur & & & & \\
\hline
\end{tabular}

(Source: data.gov.in)

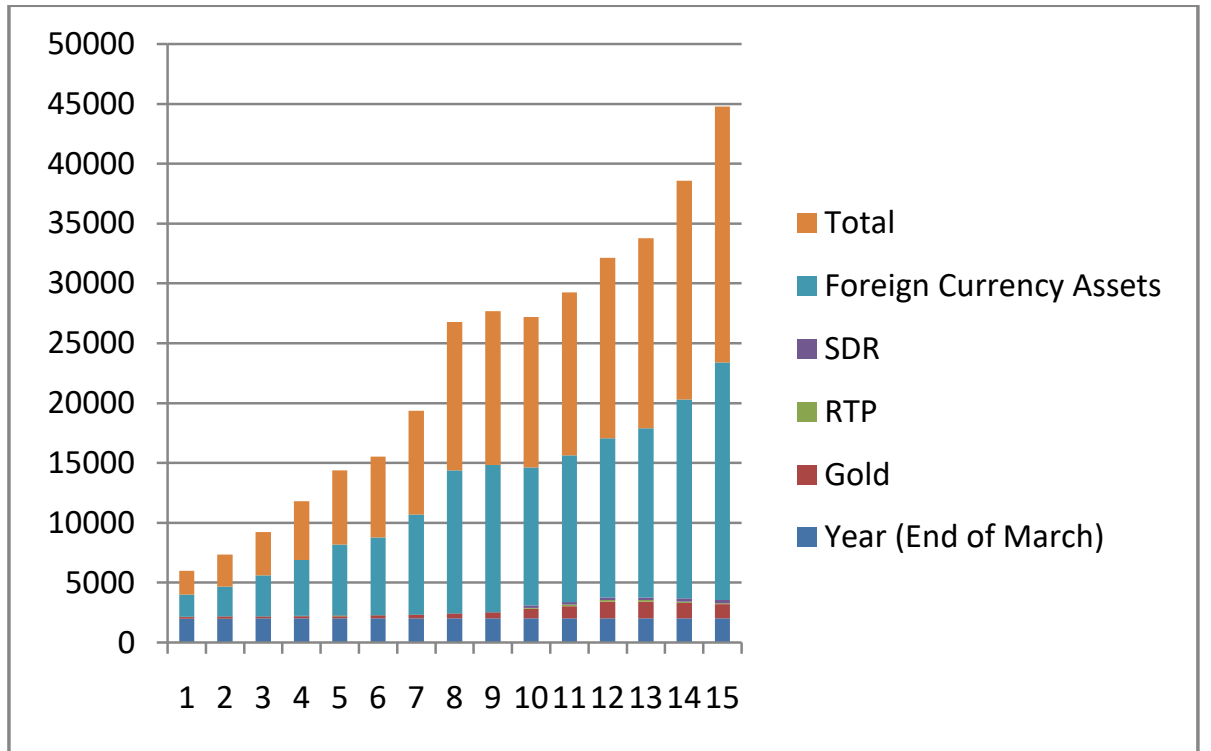

(Forex reserves from 2001 to 2015)

Gold Reserves In India From 2011 To 2015

\begin{tabular}{|l|l|l|l|}
\hline YEAR & GOLD & TOTAL RESERVES & PERCENTAGE \\
\hline 2011 & 1026 & 13610 & 7.53857458 \\
\hline 2012 & 1383 & 15061 & 9.18265719 \\
\hline 2013 & 1397 & 15884 & 8.79501385 \\
\hline 2014 & 1296 & 18284 & 7.08816452 \\
\hline 2015 & 1192 & 21376 & 5.57634731 \\
\hline
\end{tabular}

The gold reserves India was increasing from 2011 to 2013 , however there was a dip of $7.22 \%$ and again dropped to 1192(billion) in 2015. The total share of gold in Foreign exchange reserves has also fallen over the years. 


Reserve Tranche Position Over 5 Years And Its Share In Total Reser|
\begin{tabular}{|l|l|l|l|}
\hline R & $\begin{array}{l}\text { Reserve } \\
\text { Tranche } \\
\text { Position }\end{array}$ & Total Reserves & Percentage \\
\hline 2011 & 132 & 13610 & 0.969875 \\
\hline 2012 & 145 & 15061 & 0.962751 \\
\hline 2013 & 125 & 15884 & 0.786955 \\
\hline 2014 & 110 & 18284 & 0.601619 \\
\hline 2015 & 81 & 21376 & 0.37893 \\
\hline Total & 593 & 84215 & 0.70415 \\
\hline
\end{tabular}

Reserve tranche position has also declined since 2011 and stand at 81(billion) in 2015, percentage share in total reserves in 2015 is $.037 \%$. Where total reserves have increased over the years but tranche position has been falling.

Special Drwaing Rights Over Period Of Five Years

\begin{tabular}{|l|l|l|l|}
\hline Years & Sdr & Total Reserves & Percentage \\
\hline 2011 & 204 & 13610 & 1.498898 \\
\hline 2012 & 229 & 15061 & 1.520483 \\
\hline 2013 & 235 & 15884 & 1.479476 \\
\hline 2014 & 268 & 18284 & 1.465762 \\
\hline 2015 & 249 & 21376 & 1.164858 \\
\hline Total & 1185 & 84215 & 1.407113 \\
\hline
\end{tabular}

Special drawing rights showed increase since 2011-2014 but fell in 2015. In percentage terms it was $1.46 \%$ in total reserves but in 2015 it was $1.16 \%$ of total reserves.

\begin{tabular}{|l|l|l|l|}
\hline Years & Foreign Currency & Total Reserves & Percentage \\
\hline 2011 & 12249 & 13610 & 90 \\
\hline 2012 & 13305 & 15061 & 88.34075 \\
\hline 2013 & 14126 & 15884 & 88.93226 \\
\hline 2014 & 16609 & 18284 & 90.83898 \\
\hline 2015 & 19855 & 21376 & 92.88454 \\
\hline
\end{tabular}

It is the foreign currency reserves which makes most of the total reserves, about $90 \%$ of the foreign currency has share in total reserves in 2011. The trend didn't break and till 2015 foreign currency still holds major share in total reserves of about $92.8 \%$.

Components Of Total Reserve In India(2015)

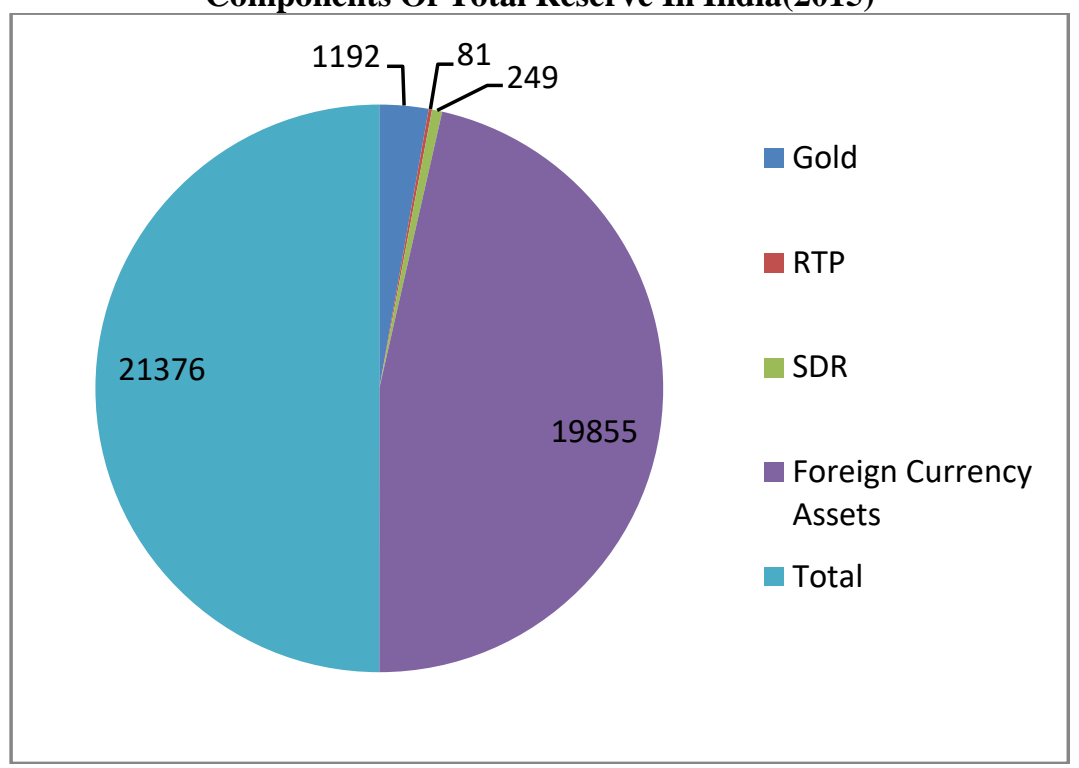

\begin{tabular}{|l|l|c|}
\hline Correlation Between & Amount \\
\hline Foreign Currency & Reserve Tranche Position & 0.611788 \\
\hline Foreign Currency & Gold & 0.862253 \\
\hline Foreign Currency & Special Drwaing Rights & 0.793628 \\
\hline
\end{tabular}




\begin{tabular}{|l|l|c|}
\hline Gold & Special Drwaing Rights & 0.951467 \\
\hline Gold & Reserve Tranche Position & 0.879479 \\
\hline Special Drwaing Rights & Reserve Tranche Position & 0.833926 \\
\hline
\end{tabular}

\section{Conclusion}

The analysis of the data reveals that foreign exchange reserves have significantly changed over the years. Total reserves have increased from 13610 billion to 21376 billion, which show an increase of 57\%. Gold reserves have fallen to 1192 billion and have a share of 5.5\% in total reserves in 2015. Reserve tranche position has also fallen to 81 billion and has a share of $.37 \%$ in total reserves. Special drawing rights stands at 249 billion with a percentage share of $1.16 \%$. foreign currency reserves stands at 19855 billion with a percentage share of $92.88 \%$, which shows that it is foreign currency reserves that are backing our foreign exchange reserves. Foreign currency reserve is the only component that has shown an increase in our period of study.

Two factors which can be stated as responsible factors for increasing reserves are capital inflows and low current account deficit.

\section{References}

[1]. http://www.investopedia.com/terms/f/foreign-exchange-reserves.asp

[2]. http://www.investopedia.com/articles/investing/033115/10-countries-biggest-forex-reserves.asp

[3]. http://www.imf.org/external/np/exr/facts/sdr.htm

[4]. https://www.imf.org/en/About/Factsheets/Sheets/2016/08/01/14/42/Gold-in-the-IMF

[5]. http://www.letslearnfinance.com/why-foreign-exchange-reserves-are-important.html

[6]. http://www.investopedia.com/articles/investing/033115/10-countries-biggest-forex-reserves.asp 